\title{
20- Tuvacanın biçimsel ses bilimi üzerine
}

Uğur ALTUNDAŞ ${ }^{1}$

APA: Altundaş, U. (2021). Tuvacanın biçimsel ses bilimi üzerine. RumeliDE Dil ve Edebiyat Araştırmaları Dergisi, (25), 323-335. DOI: 10.29000/rumelide.1036541.

$\ddot{\mathbf{O} z}$

Biçimsel ses bilimi veya morfofonoloji, biçimbirimlerin ses bilimsel olarak nasıl temsil edildiğini inceleyen bir dil bilim teorisidir. Biçimsel ses bilim, biçim bilim ile ses bilimin etkileşimi sonucunda ortaya çıkmıştır. Ses bilimsel değişmeler biçimbirimlerin eklenmesi sırasında gerçekleşir. Bu sebeple eklenme sırasında oluşan bu değişmeler genellikle eş zamanlı olarak analiz edilir. Bir ses değişimi, söz konusu değişimin hem ses bilimsel hem de biçim bilimsel koşullar altında gerçekleşmesi durumunda biçimsel ses bilim kapsamında değerlendirilir. Türk dilleri üzerine yapılan çalışmalarda biçimsel ses bilim son derece önemlidir. Gerek metin okumalarında gerekse ses bilimsel ve biçim bilimsel analizlerde biçimsel ses bilim kullanılmaktadır. Ayrıca biçimsel ses bilim, sözlük bilimi açısından da değerlidir. Bu sebeple sözlük hazırlanışında veya sözlük kullanımında mutlaka bir dilin biçimsel ses bilim özellikleri bilinmelidir. Bu çalışmada Güney Sibirya Türk dillerinden Tuvacada biçimsel ses bilim durumları ortaya koyulmuştur. Bu anlamda Tuvacada eklenmeye bağlı olarak kök, gövde veya biçimbirimlerde görülen ses değişmeleri incelenmiştir. Söz konusu biçimsel ses bilim değişmeleri, standart Tuvaca ile sınırlı tutulmuş; bu sebeple çalışmanın veri tabanı güncel Tuva edebiyat eserlerinden, ders kitaplarından ve sözlük çalışmalarından oluşturulmuştur. Ayrıca eklenme sırasında Tuvacanın genel ses bilim ve biçim bilim özelliklerinden kaynaklanan ünlü uyumları ve ünsüz benzeşmeleri biçimsel ses bilimi kapsamında değerlendirilmemiştir. Bu çalışmada biçimsel ses değişmeleri, eş zamanlı olduğu kadar art zamanlı olarak da analiz edilmiştir. Bunun sebebi, kimi biçimsel ses değişmelerinin kalıplaşarak yeni sözlük birimler oluşturmasıdır. Böylece Tuvacada biçimsel ses bilim kaynaklı söz yapımının da betimlenmesi amaçlanmıştır.

Anahtar kelimeler: Tuvaca, ses bilim, biçim bilim, biçimsel ses bilim

\section{On the Morphonology of Tuvan}

\begin{abstract}
Morpho-phonology or morphophonology is a linguistic theory that studies how morphemes are represented phonologically. Morphophonology has emerged as a result of the interaction of morphology and phonology. Phonological changes occur during the addition of morphemes. For this reason, these changes during addition are usually analyzed synchronically. A phonetic change is considered within the scope of morphophonology if the change takes place under both phonological and morphological conditions. Morphophonology knowledge is important in studies on Turkic languages. Morphophonology information is used in both text reading and phonological and morphological analysis. In addition, morphophonology is valuable in terms of lexicography. For this reason, the morphophonemic features of a language must be known in the preparation of a dictionary or in the use of a dictionary. In this study, the morphophonemic status of Tuvan, one of the Southern
\end{abstract}

Arş. Gör., Hacettepe Üniversitesi, Edebiyat Fakültesi, Sosyal Bilimler Enstitüsü, Türk Dili ve Edebiyatı Bölümü, Türk Dili (Ankara, Türkiye), ualtundas@gmail.com, ORCID ID: oooo-0002-7762-0211 [Araştırma makalesi, Makale kayıt tarihi: 08.11.2021-kabul tarihi: 20.12.2021; DOI: 10.2900o/rumelide.1036541]

Adres | Address

RumeliDE Dil ve Edebiyat Araşturmaları Dergisi Osmanağa Mahallesi, Mürver Çiçeği Sokak, No:14/8 Kadıköy - ISTANBUL / TÜRKIYE 34714 e-posta: editor@rumelide.com

RumeliDE Journal of Language and Literature Studies Osmanağa Mahallesi, Mürver Çiçeği Sokak, No:14/8

Kadıköy - ISTANBUL / TURKEY 34714 tel: +90 $5057958124,+902167730616$

mail: editor@rumelide.com,

phone: +90 5057958124, +90 2167730616 


\begin{abstract}
Siberian Turkic languages, has been revealed. In this sense, sound changes in root, stem or morphemes, depending on the addition in Tuvan, were examined. The morphophonemic changes in question were limited to the standard Tuvan language; For this reason, the database of the study was created from current Tuvan literary works, textbooks and dictionary studies. In addition, vowel harmony and consonant assimilations arising from the general phonetic and morphological features of Tuvan were not evaluated within the scope of morphophonology. In this study, morphophonemic changes were analyzed diachronically as well as synchronically. The reason for this is that some morphophonemic changes become stereotypes and create new lexical units. Thus, it is aimed to describe the word coinage in Tuvan based on formal phonetics.
\end{abstract}

Keywords: Tuvan, phonology, morphology, morphophonology

\title{
Giriş
}

Biçim bilimsel analiz bir sözcüğü bileşenlerine ayırma işlemidir. Türkçe gibi tüm eklemeli dillerde bu analiz; kök, biçimbirim ve bunların kategorik özelliklerini belirler. Türkçede biçimbirimlerin ses bilimsel olarak farklı birçok alt biçimbirimi vardır. $\mathrm{Bu}$ alt biçimbirimler, biçimbirimlerin sıralama sınırlılıklarından etkilenmez. Ancak kimi kök, gövde veya biçimbirimler, birlikte kullanıldığı ses veya biçimbirime göre birtakım ses değişmelerine uğrayabilir. Bir başka deyişle, ses olaylarının sebeplerinden biri de eklenmedir. Buna göre ses değişmelerinin önemli bir bölümü eklenme sırasında ortaya çıkar (Demir ve Yılmaz 2018: 75). Biçimsel ses bilim veya morfofonoloji terimiyle ele alınan bu durum, basitçe biçimbirimlerin ses bilimsel olarak nasıl temsil edildiğini inceleyen bir dil bilim teorisidir. Bu açıdan biçimsel ses bilim, bu iki dil bilgisi alanı arasında bir ara yüz olarak kabul edilmektedir. Bir başka deyişle biçimsel ses bilim, biçim bilim ile ses bilimin etkileşimi sonucunda ortaya çlkmıştır. Ses bilimsel değişmeler biçimbirimlerin eklenmesi sırasında gerçekleşir. Bu sebeple eklenme sırasında oluşan bu değişmeler eş zamanlı olarak analiz edilebilmektedir. Bir ses değişiminin biçimsel ses bilim kapsamında değerlendirilebilmesi için söz konusu değişimin hem ses bilimsel hem de biçim bilimsel koşullar altında gerçekleşmesi gerekir (Aslan 2006: 546).

Türk dilleri üzerine yapılan çalışmalarda biçimsel ses bilim önemlidir. Gerek metin okumalarında gerekse ses bilimsel ve biçim bilimsel analizlerde biçimsel ses bilim kullanılmaktadır. Ayrıca biçimsel ses bilim, sözlük bilimi açısından da değerlidir. Bu sebeple sözlük hazırlanışında veya sözlük kullanımında mutlaka bir dilin biçimsel ses bilim özellikleri bilinmelidir.

Bu çalışmada Güney Sibirya Türk dillerinden Tuvacada eklenme sırasında ortaya çıkan ses değişmeleri ortaya koyulmuştur. Bu anlamda eklenmeye bağlı olarak kök, gövde veya biçimbirimlerde görülen ses değişmeleri incelenmiştir. Söz konusu biçimsel ses bilim değişmeleri, standart Tuvaca ile sınırlı tutulmuş; bu sebeple çalışmanın veri tabanı güncel Tuva edebiyat eserlerinden ve sözlük çalışmalarından oluşturulmuştur. Ayrıca eklenme sırasında Tuvacanın genel ses bilim ve biçim bilim özelliklerinden kaynaklanan ünlü uyumları ve ünsüz benzeşmeleri biçimsel ses bilim kapsamında değerlendirilmemiştir. Bu çalışmada biçimsel ses değişmeleri, eş zamanlı olduğu kadar art zamanlı olarak da analiz edilmiştir. Bunun sebebi, kimi biçimsel ses değişmelerinin kalıplaşarak yeni sözlük birimler oluşturmasıdır. Türk dillerinde sözcük yapımının pek çok yolu vardır. Bunlardan en önemlisi şüphesiz ekleme yoluyla söz yapımıdır. Ancak çoğu zaman bir sözcük türetiminde biçim bilime ses bilim de eşlik etmektedir. Yani, bir sözcük ile başka bir sözcüğün veya sözcüğe eklenen ekin kalıplaşması olarak tanımlanabilen bu türetmede çoğu zaman sözcükte, ekte veya her ikisinde birden birtakım ses değişmeleri yaşanmaktadır. Dolayısıyla biçimsel ses bilim, sözcük türetme yollarından biridir (Türkçede

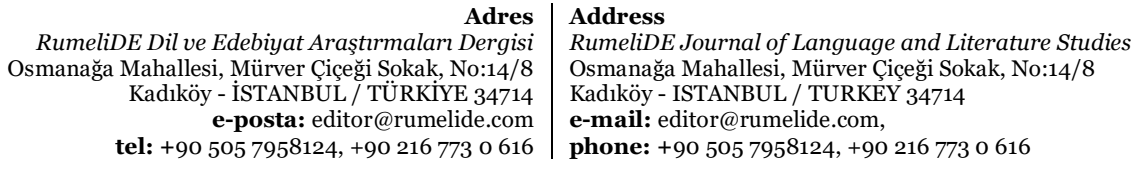


biçimsel ses bilim yoluyla sözcük türetme örnekleri için bkz. Hazar 2015). Bu sebeple çalışmada Tuvacada biçimsel ses bilim kaynaklı söz yapımının da tespit edilmesi amaçlanmıştır.

\section{Tuvacada biçimsel ses bilim değișmeleri}

Bir Türk dilinde meydana gelen biçimsel ses bilim değişmelerini farklı şekillerde sınıflandırmak mümkündür. Bunun temel sebebi, bu bilim dalının ses bilim ve biçim bilim olmak üzere iki temel dil bilgisi alanıyla ilgili olmasıdır. Dolayısıyla biçimsel ses bilimini tek bir kritere göre sınıflandırmak mümkün değildir. Eklenme sırasında oluşan bir ses bilimsel değişmede hem biçim bilim hem de ses bilim etkili olmaktadır. Bu çalışmada Tuvacada görülen biçimsel ses bilim değişmeleri, Sema Aslan'ın Türkiye Türkçesinin Morfonolojisi Üzerine adlı çalışması ile Maral Töre'nin Türkmencenin Morfofonolojisi adlı tezinde kullanmış olduğu sınıflandırmadan yararlanılarak tasnif edilmiştir. Buna göre çalışma; sözcük tabanında görülen biçimsel ses bilim değişmeleri, sözcük tabanı ile ek sınırında görülen biçimsel ses bilim değişmeleri, biçimsel ses bilim kaynaklı ikincil ünlü uzunlukları ve biçimsel ses biliminden kaynaklanan benzeşmeler olmak üzere dört temel başlıktan oluşmaktadır.

\subsection{Sözcük tabanında görülen biçimsel ses bilim değişmeleri}

Sözcük tabanında görülen biçimsel ses bilim değişmeleri, eş zamanlı ve art zamanlı olarak iki şekilde açıklanabilmektedir.

\subsubsection{Sözcük tabanında eş zamanlı biçimsel ses bilim değişmeleri}

Sözcük tabanında eş zamanlı biçimsel ses değişmeleri, sözcüğün ünlü ile başlayan bir ek alması sonucu gerçekleşir. Bu ses değişmesi, geniş veya dar orta hece ünlüsünün sıfırla nöbetleşmesi biçiminde görülür. Vurgusuz ünlülerin düşmesi, hemen hemen tüm Türk dillerinde görülen bir ses olayıdır. Tuvacada özellikle dar ünlüler, çoğu zaman ünlüyle başlayan eklerden önce ve dar ünlüden oluşan kapalı hecelerle sona eren gövdelerde vurgusuz orta hece ünlüsü konumuna gelerek düşerler (İshakov ve Palmbah 2019: 45). Aşağıdaki ilk tümcede yer alan arn "yüz" ile ikinci tümcede görülen moyun "boyun" sözcüklerinde ünlü ile başlayan üçüncü tekil kişi iyelik eki eklendiğinde vurgusuz orta hece ünlüleri düşmüştür:

Ooy arnı şiriin. "Onun yüzü sert” (TRS 575)

Hülbüs moynunuঘ kejinden kllgan. "Geyiğin boyun derisinden yapılmıştır.” (Kara-ool 2013: 123).

\subsubsection{Sözcük tabanında art zamanlı biçimsel ses bilim değişmeleri}

Sözcük tabanında art zamanlı biçimsel ses bilim örnekleri ise, tarihsel olarak bir sözcügün aldığı ek veya birleştiği bir başka sözcükle birlikte sözlükselleşmesi sonucu ortaya çıkmıştır. Bu anlamda iki sözcüğün birleşmesi sırasında iki ünlü arasında kalan /ç/ ve /ş/ sesleri /j/ sesine, /s/ sesi /z/ sesine değişir. Aşağıdaki birinci ve ikinci tümcede görülen çugaajok < çugaa + çok ve ergejok < erge + çok sözcüklerinde -ç- > -j- (çugaa ve erge sözcükleriyle birleşerek yeni bir sözcük oluşumunu sağlayan çok sözcüğünün /ç/ sesi, birleşme sırasında /j/ sesine değişmiştir); üçüncü tümcedeki üjen < üş on sözcüğünde -ş- > -j- (on sözcüğü ile birleşen üş sayısının /ş/ ünsüzü, /j/ sesine değişmiştir) ve dördüncü tümcedeki sezen < ses + on ve tozan < tos + on sözcüklerinde de $-\mathrm{s}->-$ - - değişiminin örnekleri görülmektedir (on sözcüğü ile birleşme sırasında iki ünlü arasında kalan /s/ sesi, /z/ sesine değişmiştir):

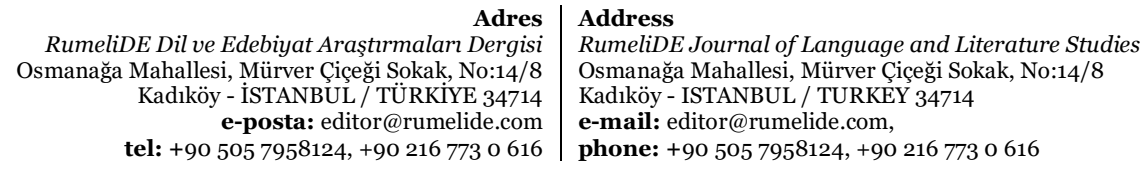


Am ol bögün baza sadıg kılıp kelgeni çugaajok. “Onun bügün de satın aldığı şüphesizdir.” (Dongak 2010: 53).

Sıldıstar çügle onza çaraş bolup deerde köstüp turar eves, a harın Çer kırında ajıl-amıdıralga ergejok çugula hamaarılgalı. "Yıldızlar sadece bir çeşit güzellik olup gökyüzünde durmaz, onlar aynı zamanda yer yüzünde yaşam için son derece önemlidir.” (Monguş ve Kuular 1995: 243).

... üjen minut iştinde çayhg kılaştap çede beer. “... otuz dakika içinde rahatllkla yürüyerek yetişebilir.” (Kuular 2002: 8).

Aldan, çeden, sezen, tozan çıldarnı ayalgaları, rrları kuttulgan. “Altmış, yetmiş, seksen ve doksanlı yılların besteleri ve şarkıları yayılmıştır.” (Kuular 2002: 45).

Yukarıdaki dördüncü tümcede görülen aldan ve çeden (aldan < aldı on, çeden < çedi + on) örneklerinde ise iki sözcük birleşirken sırasıyla /1/ ve /i/ ünlüleri düşmüş ve on sözcüğündeki /o/ ünlüsü, dudak uyumuna bağlı olarak /a/ ve /e/ sesine değişmiştir (Koçoğlu Gündoğdu 2012: 51).

Sözcük tabanında iki sözcüğün birleşmesi neticesinde art zamanlı biçimsel ses bilim değişmelerine bir başka örnek, işaret zamirleri ile teg edatının birleşmesi verilebilir. Aşağıdaki ilk tümce $m \imath n d \imath g<m o+n \imath$ teg, ikinci tümce ise $\imath n d \imath g<$ anı teg $<o l+n \imath$ teg yapısını örneklendirmektedir:

Baydalıvısı mındıg-la dır bo, Noyan - digen. "Hükümdar, durumumuz işte böyledir, dedi." (Suvay 2009: 38).

Seè ındıg ejï bar be? “Senin öyle arkadaşın var mı?” (Kara-ool 2013: 127).

mındıg sözcüğ̈̈, monı teg ilgeç öbeğinin sözlükselleşmesi sonucu oluşmuştur. Öbek yapı oluşumunda teg ilgecinin istemi gereği, söz başı b- > m- değişimine uğrayan bo zamiri belirtme durum eki almıştır. Ancak sözlükselleşme sürecinde belirtme durum ekinin ünlüsü düşmüş ve bo sözcüğünün yuvarlak geniş ünlüsü /o/ ile teg sözcüğünün düz geniş ünlüsü /e/ sesi daralarak düz dar ünlüsü /1/ sesine değişmiştir. ındıg sözcüğünde ise ol zamirinin teg edatı ile sözlükselleştiği görülmektedir. mındıg yapısında olduğu gibi burada da belirtme durum ekinin ünlüsü düşmüş; ol zamirinin yuvarlak geniş ünlüsü /o/ ve teg edatının düz geniş ünlüsü /e/ sesi daralarak /1/ olmuştur.

Tuvacada henüz dilbilgiselleşme sürecini tamamlamamış, sözlüklerde ayrı bir madde başı olarak ele alınmayan ancak birleşme sırasında ses değişimine sebep olan ve iki eylemi bir araya getiren bir başka yapı söz konusudur. Bu yapı; eylem + -p zarf-fiil eki + $\imath d-+$-ar geniş zaman eki biçimindedir:

Ijjeeninge ol oktyabr' aydan mayga çedir çıdıptar. "(Ayı) ininde ekim ayından mayıs ayına kadar yatar." (Monguş ve Kuular 1995: 31)

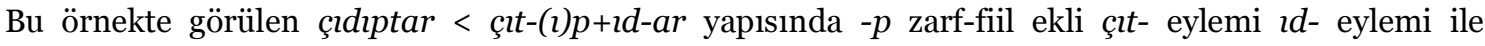
birleşmiştir. Bu birleşme sırasında $\imath d$ - eyleminin ünlüsü düşmüş; /d/ ünsüzü ise ünsüz benzeşmesi neticesinde /t/ sesine değişmiştir.

Sözcük tabanında art zamanlı biçimsel ses bilim kaynaklı ses değişimine bir başka örnek, birleşik sözcük kuruluşu sırasında yan yana gelen iki ünlüden birinin birleşme sırasında düşmesidir (Koçoğlu Gündoğdu 2012: 56). Aşağıdaki tümcede çaa ve ava sözcüklerinin birleşmesiyle oluşan çaava "yenge" sözcüğü bunun bir örneğidir:

Daayım, küüyüm, akım, çaavam, ugbam, çestem, çeenim, duymam deen ışkaş törel yozuzunuy eeldek, eviley sösterin çugaa sanında ajıglaarı çayçıl turgan. "Dayım, dayımın karısı, ağabeyim, yengem, ablam, eniştem, yeğenim, kardeşim gibi akraba âdetlerinin nazik sözlerini her sohbette kullanmak bir gelenekti.” (Monguş ve Kuular 1995: 157).

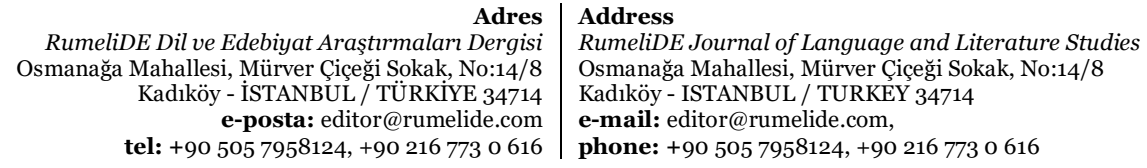


deeş, adaanga, ındı, murnuu gibi sözcüklerde görülen biçimsel ses bilim değişmeleri, art zamanlı olarak bir sözcüğ̈̈n aldığı ek ile birlikte kalıplaşmış olduğu örneklerdir. Söz konusu örnekler, Tuvacada ikincil uzun ünlüye birer örnek oldukları için biçimsel ses bilim kaynaklı ikincil ünlü uzunlukları bölümünde örneklendirilmiştir.

\subsection{Sözcük tabanı ile ek sınırında görülen biçimsel ses bilim değișmeleri}

Tuvacanın tipik biçimsel ses bilim özellikleri, çoğunlukla sözcük tabanı ile ek sınırında görülmektedir. $\mathrm{Bu}$ biçimsel ses bilim değişmelerinin temel nedeni, kimi seslerin iki ünlü arasında değişmesidir. Bu değişimler, çoğunlukla iyelik eklerinin eklenmesi sırasında yaşanmaktadır. Söz konusu değişmeler, eş zamanlı olarak gerçekleşmektedir. Tuvacada iki ünlü arasında kalma durumuna göre görülen biçimsel ses bilim değişmeleri şunlardır:

\subsection{1. $-t->$-d- değişimi}

-t- > -d- değişimi, /t/ ünsüzüyle biten sözcüklerin ünlü ile başlayan bir ek almaları durumunda görülür. Aşağıdaki örnekte sat- eyleminin / $t$ / ünsüzü, iki ünlü arasında /d/ olmuştur:

Dadar-oolga açazı çadag-terge sadıp bergen. "Dadar-ool için annesi bisiklet satın aldı." (Kara-ool 2013: 126).

\subsection{2. $\mathrm{k}$ ve $\mathrm{g}>$ Ø Nöbetleşmesi}

/k/ veya /g/ ünsüzleriyle biten sözcüklere ünlü ile başlayan bir ek getirildiğinde söz konusu / k/ veya /g/ ünsüzleri sifırla nöbetleşir:

... sostavtıg kılıg sözünüy kezee-daa kıldır hereglettiner. “... birleşik eylemin bir parçası olarak kullanılır.” (Monguş ve Kuular 1995: 84).

Buradaki biçimsel ses bilim değişmesine, ikincil ünlü uzunlukları bölümünde ayrıca değinilecektir.

\subsection{3. -k- > -g- Değişimi}

Tuvacada eklenme sırasında iki ünlü arasında -k- > -g- değişimi görülmektedir. Aşağıdaki örnekte çaak "yanak" sözcüğünün /k/ ünsüzü, iyelik eki alarak iki ünlü arasında /g/ sesine değişmiştir:

Hoyag ögje kire beerge, açazı oglunuy çaagından keep çıttaan. "Hoyag eve girince, annesi oğlunun yanağından kokladı.” (Lodoydamba 2005: 69).

\subsection{4. - p > -v- Değişimi}

Tuvacada iki ünlü arasında /p/ sesi, /v/ olmaktadır. Aşağıdaki tövünden örneğinde "merkez" anlamına gelen töp sözcüğünün /p/ sesi, iki ünlü arasında /v/ olmuştur:

Inda bajınnar hooray tövünden dıka kıdıg çerde. "Orada evler şehir merkezinden çok uzakta." (Dongak 2010: 87)

\subsection{5. -ş- > -j- Değişimi}

Eklenme sırasında iki ünlü arasında kalan /ş/, sesi Tuvacada /j/ sesine değişir. Aşağıdaki bajın "başını" sözcüğünde baş sözcü̆üünün /ş/ sesi, iyelik eki eklendiğinde iki ünlü arasında kalarak /j/ olmuştur:

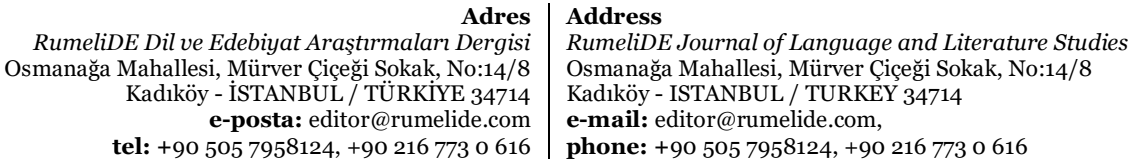


Ooy soonda bajın çaybışaan çugaalaan. "Ondan sonra başını sallayarak konuştu." (Kara-ool 2013: 27)

\subsection{6. $-\mathrm{s}->$-z- Değişimi}

Tuvacada /s/ sesi, iki ünlü arasında /z/ sesine değişir. Buna örnek olarak aşağıdaki doozul- eyleminde doos- "bitirmek, sona erdirmek" sözcüğünün /s/ sesi, edilgenlik ekini aldığında iki ünlü arasında kalarak /z/ sesine değişmiştir:

Kejeenin bayırlıg kezee inçaldır doozulgan. "Gecenin veda bölümü böylece son buldu." (Monguş ve Kuular 1995: 121)

\subsection{7. -ş- > -ç- Değişimi}

Tuvacada -ş- işteşlik eki, iki ünlü arasında /ç/ olur ve vurgusuz orta hece ünlüsü düşer. Bu anlamda aşağıdaki tümcede görülen çetçir < çet-(i)ş-ir sözünde işteşlik ekinin /ş/ sesi, /ç/ sesine değişmiş ve vurgusuz orta hece ünlüsü düşmüştür:

A’ş-çemin çetçir. "Senin yemeğin yeterli olur.” (Dongak 2010: 78).

\subsection{Biçimsel ses bilim kaynaklı ikincil ünlü uzunlukları}

Tuvacada eklenme sırasında kimi sesler iki ünlü arasında düşer ve ikincil ünlü uzunluğu meydana gelir. Söz konusu biçimsel ses bilim değişmeleri, sözcük tabanında ve eklenme sırasında olmak üzere iki şekilde gerçekleşir:

\subsubsection{Sözcük tabanında görülen ikincil ünlü uzunlukları}

Sözcük tabanında biçimsel ses bilim kaynaklı ünlü uzunlukları, art zamanlı olabileceği gibi eş zamanlı da olabilmektedir. Art zamanlı ikincil ünlü uzunluklarında tarihsel olarak bir ekin sözcükle birleşerek sözlükselleştiği görülmektedir. Bu anlamda de-eylemi ile -geş zarf-fiil ekinin kalıplaşmasından oluşan deeş ilgeci buna bir örnektir. Burada iki ünlü arasında kalan -/g/ sesi düşer ve ikincil ünlü uzunluğu oluşur:

Ol deeş avam erten durgu çemeledi. "Onun için annem sabah sürekli sitem etti.” (Kara-ool 2013: 26)

Ayrıca deeş sözcüğünün "diyerek, diye” anlamlarında zarf-fiil yapısında da kullanıldığı görülür. Bu durumda yaşanan biçimsel ses bilim değişimi eş zamanlı olarak gerçekleşmektedir:

Men ryap-la baar men - deeş, Çinçivaa aalınçe halaan. "Çinçivaa, ben mutlaka gideceğim diyerek evine doğru yöneldi” (Monguş ve Kuular 1995: 43).

1.1.2 bölümünde sözcük tabanında art zamanlı biçimsel ses bilim değişmelerine örnek olarak deeş sözcüğü ile birlikte adaanga, ındı, murnuu gibi sözcükler verilmiştir. Bu sözcüklerde eklenen biçimbirimler, sözcük tabanı ile kalıplaşarak yeni bir sözcük oluşturmuştur. Sözlükselleşme sürecinden önce ek sınırında 1.2.2. k ve g > Ø Nöbetleşmesi bölümünde değinilen iki ünlü arasında /k/ veya /g/ sesinin düşmesi hâdisesi yaşanmıştır. adaanga sözcüğünde, adak sözüne üçüncü tekil kişi iyelik eki gelmiş; bu sırada söz sonu /k/ sesi düşmüş ve ikincil ünlü uzunluğu meydana gelmiştir. Sözcüğe yönelme durum ekinin eklenmesiyle birlikte adaanga yapısı ortaya çıkmıştır. Söz konusu biçimsel ses değişmeleri art zamanlıdır ve bu biçimiyle kalıplaşmıştır. Ancak söz konusu -k- > Ø nöbetleşmesinin eş

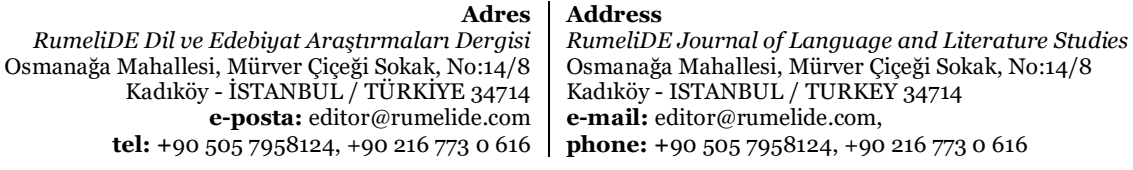


zamanlı bir ses değişimi olarak görülebildiği unutulmamalıdır. Burada sözcük kalıplaştığı için söz konusu biçimsel ses bilim değişimi sözcük tabanında kabul edilmiştir:

Hatan-Bator Magsarjaptın komandılalını adaanga kançaar çaalajıp çoraanın çugaalaan.

"Hatan-Bataor Magsarjap’ın kumandası altında nasıl savaştı̆̆ını anlattı." (Lodoydamba 2005: 70).

Aynı şekilde ındı ve murnuu sözcüklerinde aitlik ekinin eklenmesi sırasında bir biçimsel ses bilim değişimi yaşanmıştır. murnu sözcüğünün sonundaki -u'nun iyelik eki olduğu açıktır. ındı sözcüğünde ise sondaki -ı ünlüsü Ölmez’e göre Uygurca ıntın sözcüğünden gelmektedir (2007: 179). ındı ve murnu biçiminde ünlü ile biten sözcüklere eş zamanlı olarak bakıldığında $-k \imath$ aitlik ekinin getirilmesi gerekirdi (Tosun 2011: 247). Ancak her iki sözcükte de iki ünlü arasında kalan /k/ ünsüzü düşmüş, böylece ikincil ünlü uzunluğu meydana gelmiştir. Ayrıca sözcükler bu biçimiyle kalıplaşarak standart Tuvacada aitlik ekinin kullanımından farklı bir görünüm sergilemektedir:

Borbak bajınnın ındı talazında angli dıl başkılap kelgen. "Borbak evin öteki tarafında İngilizce öğretti." (Kuular 2002: 192)

Deerde buluttar dalajı aajok sopgu tayga bajından murnuu çükçe köjüp turgan... "Gökyüzünde bulutlar, aceleyle kuzey ormanlarının ucundan güneye yönelmiş...” (Monguş ve Kuular 1995: 195).

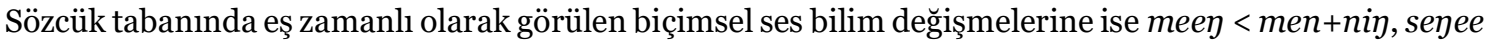
$<s e n+g e, o o \eta<o l+n u \eta$, oon $<o l+d a n$, moon $<b o+n+d a n$ gibi kişi ve işaret zamirlerinin durum ekleriyle çekimlenmesi örnek verilebilir. men ve sen zamirlerinin ilgi ve yönelme durum ekli çekimlerinde; ol zamirinin ilgi, yönelme ve ayrılma durum eki çekimlerinde ve bo zamirinde ise ilgi, yönelme ve ayrılma durum eki çekimlerinde ikincil ünlü uzunluğu ortaya çıkar (İshakov ve Palmbah 2019: 43):

Meey açam zavodta injener kiji. "Benim annem fabrikada mühendis.” (Monguş ve Kuular 1995: 200).

Seen-bile amırlajıp alır deeş keldim. "Seninle selamlaşmak için geldim.” (Monguş ve Kuular 1995: 223).

Çogaaldı maadırı seyee çüü dep süme kadıp turar-dır? "Eserin kahramanı sana nasıl bir öğüt veriyor?” (Kara-ool 2013: 126).

Ooy ornunga kiji herek apargan. “Onun yerine başka birisi gerekti.” (Dongak 2010: 99)

Tıva tooldarnı oon öske kandıg söster-bile egeleeş, töndürüp turarıl? "Tuva destanları ondan başka hangi sözlerle başlayıp bitirilir?” (Kara-ool 2013: 108).

Inçan ayaa, İyama kılaştap kelgen. "O zaman İyama oraya yürüyerek geldi.” (Lodoydamba 2005: 16).

Mayaa çüge maşinalar, döö ol garajka çügle traktorlar, kombaynnar turgan. "Burada sadece arabalar, şuradaki garajda ise sadece traktörler ve biçerdöverler duruyor.” (Dongak 2010: 17).

Moỏ murnunda, şag şaandan beer, ... "Bunun öncesinde, eskiden beri ...” (Kuular 2002: 85)

Men moon uraar eves men. "Ben buradan uzaklaşmiyorum.” (Kara-ool 2013: 103).

\subsubsection{Sözcük tabanı ile ek sınırında görülen ikincil ünlü uzunlukları}

Biçimsel ses bilim kaynaklı sözcük tabanı ile ek sınırında görülen ikincil ünlü uzunlukları, eş zamanlı birer nöbetleşme olayıdır. Çoğunlukla /g/ veya / / ünsüzüyle biten sözcüklere iyelik eklerinin eklenmesi sırasında görülür. Bu durumda $/ \mathrm{g} /$ ve / $\mathrm{k} /$ sesleri sıfirla nöbetleşir ve iyelik ekinin dar ünlüsü, sözcük kökündeki ünlüye göre dudak uyumuna girer. Buna örnek olarak, aşağıdaki ilk tümcede ög sözcüğü, iyelik eki alarak /g/ ünsüzünü yitirmiş ve sözcükte ikincil ünlü uzunluğu meydana gelmiştir. İkinci

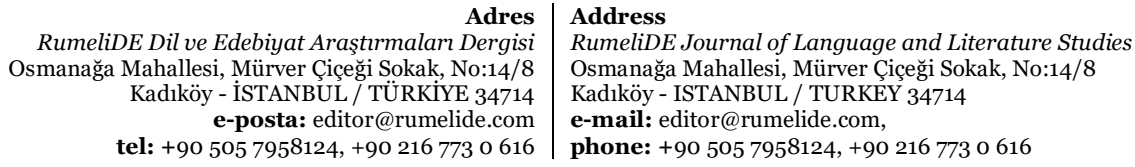


tümcede ise / $\mathrm{k} /$ ünsüzüyle biten karak sözcüğünün iyelik eki alması durumunda ortaya çıan ikincil ünlü uzunluğu örneklendirilmiştir. Söz konusu biçimsel ses bilim değişimlerinde hem sözcük tabanı hem de biçimbirim etkilenmektedir:

Çalatpaan aalçı ooy öönge çüge çedip kelgeni ol? "Davet edilmeyen misafir onun evine niçin gelmiş?” (Lodoydamba 2005: 37).

Karaanı strıy kirbikteri bajını dügünge dömeyleşkek. "Gözlerinin yoğun kirpikleri saçlarına benziyor." (Dongak 2010: 110).

Yukarıdaki örneklerden hareketle ünlü ile başlayan bir ek, /g/ veya /k/ ünsüzü ile biten bir sözcüğe eklendiğinde /g/ ve / $\mathrm{k}$ / sesleri düşmekte ve böylece ikincil ünlü uzunluğu oluşmaktadır. Bu duruma benzer bir başka ikincil ünlü uzunluğu ise ünlü ile biten sözcüklere veya olumsuzluk eki almış eylemlere $(-B A) / g /$ ünsüzü ile başlayan eklerin getirilmesi sırasında yaşanmaktadır. Bu durum yaygın olarak, GAn (sıfat-fiil veya geçmiş zaman eki; ekin ad yapımında kullanımı için bkz. Tosun 2021: 131-134) ve $g A s ̧$ (zarf-fiil) eklerinde görülür. Bu ekler dışında yaygın olmasa da $-G A$ yönelme eki, $-g A L A$ ve $-g I j A$ zarf-fiil ekleri, $-g A l A k$ gelecek zaman eki ve $-g A y$ istek eki de ünlü ile biten sözcüklere eklendiklerinde ikincil ünlü uzunluğu oluşabilir. Söz konusu durumda yaşanan eş zamanlı ikincil ünlü uzunluğu, $-g A n$ ve $-g A s ̧$ eklerinde sistematik bir nöbetleşme olayına dönüşmüşken /g/ ile başlayan diğer eklerde nadiren görülmektedir:

Ol üyede eleen elbek ça’s-daa çaggılaan çüve. "O zamanlarda yeterince çok yağmur yağmıştır” (Monguş ve Kuular 1995: 161).

Adazı oglu-bile bazaarje bar çoraaş, arga iştinge krokodilge tavarjı bergen. "Babası oğlu ile pazara giderken, ormanda timsahla karşılaştı.” (Kara-ool 2013: 135).

Onu doraan olurtup kaan. "Onu hemen oturttu” (Monguş ve Kuular 1995: 161).

Aynur sezonu egeleele, açam höy dï̄ ölürdü. "Av sezonu başlayalı babam çok sincap öldürdü.” (Monguş ve Kuular 1995: 90).

Tıvaga ınçan rok högjüm barık çok dep bolur, çaa-la egeleelek. "Tuvada o zamanlar rak müzik hemen hemen hiç yoktur, yeni yeni başlamak üzere.” (Kuular 2002: 42).

Duu-la Kudajı azı Sürüy-ool bijeen bolza, ulus nomçaay-daa, sonurgaay-daa deg. "İşte Kudajı veya Sürüy-ool yazsa da insanlar okuyup beğense.” (Kuular 2002: 137).

Arıg-şever, silig kijee aarıg-arjıg haldaar eves. "Temiz kimseye hastalık bulaşmaz." (Monguş ve Kuular 1995: 250).

Yukarıdaki ilk örnekte ünlü ile biten çaggıla- eylemi -gan geçmiş zaman ekini aldığında /g/ ünsüzü düşmüş ve ikincil ünlü uzunluğu oluşmuştur. İkinci tümcede, bar çoru- yapısında /u/ ünlüsü ile biten yardımcı eyleme -gaş zarf-fiil eki getirilmiş; bu durumda iki ünlü arasında kalan /g/ düşmüş ve benzeşme sonucu -u- > -a- değişimi yaşanmıştır. Söz konusu ünlü değişimi Tuvacada tipik bir biçimsel ses bilim olayıdır. Yani, /u/ ile biten eylemlere /g/ ile başlayan ekler getirildiğinde söz sonu /u/ ünlüsü /a/ ünlüsüne değişir ve ikincil ünlü uzunluğu meydana gelir. Üçüncü tümcede, $-G A n$ ekinin getirildiği eylem ünlü ile değil, /g/ ünsüzüyle bitmektedir. Bu durumda - GAn eki eklendiğinde yan yana gelen her iki /g/ ünsüzü de düsser ve ikincil ünlü uzunluğu ortaya çlkar (olurtup kaan < olurt-up kag-gan). Dördüncü tümcede egeleele yapısında egele- "başlamak" eylemine - gAlA zarf-fiil eki getirildiğinde /g/ sesi düşmüş ve ikincil uzunluk oluşmuştur. Beşinci tümcede egeleelek yapısında yine egele- "başlamak" eylemine - gAlAk eki getirilmiş; bu durumda /g/ ünsüzü düşmüş ve ikincil ünlü uzunluğu meydana gelmiştir. Altıncı tümcede ise ünlü biten bir sözcüğe /g/ ünsüzü ile başlayan $-G A$ yönelme ekinin getirilmesi sırasında oluşan ikincil ünlü uzunluğu gösterilmiş̧ir.

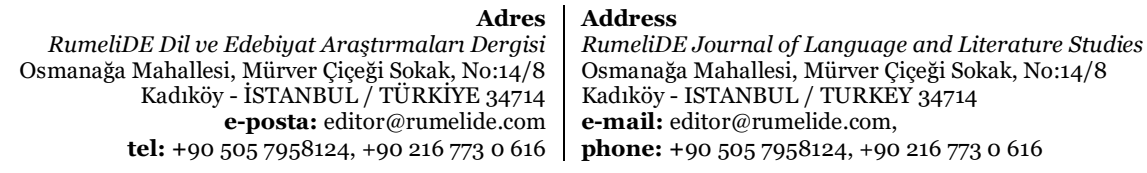


Ayrıca biçimsel ses bilim kaynaklı eş zamanlı sözcük tabanı ile ek sınırında ikincil ünlü uzunluklarına, /r/ ve /l/ ile biten kimi tek heceli eylemlerin $-X r$ ekini (gelecek zaman, geniş zaman veya ad-eylem olabilir) alması sırasında rastlanır. Bu örneklerin sayısı sınırlıdır. Sadece kel-, bol-, kör-, ber- ve bareylemlerinde görülür. Bu eylemlere $-X r$ eki eklendiğinde söz sonu /r/ veya /l/ sesleri düşer ve ikincil uzun ünlü ortaya çıkar. Söz konusu biçimsel ses bilim değişiminin eş zamanlı olarak görülmediği örnekler de bulunmaktadır. Aşağıdaki ilk tümcede $-X r$ ad-eylem ekini alan kel- eyleminin /l/ ünsüzü düşmüş ve ikincil uzunluk meydana gelmiştir. İkinci tümcede ise kel- eylemi yine $-X r$ ekini almasına karşın söz konusu biçimsel ses bilim değişimi olmamıştır. Ayrıca ikinci tümcede $-X r$ ekini alan boleyleminde /l/ ünsüzü düşmüş ve ikincil uzun ünlü oluşmuştur. Üçüncü, dördüncü ve beşinci tümcede ise $b e r-, k o ̈ r-v e ~ b a r-$ eylemlerinin $-X r$ ekini aldığında görülen ikincil ünlü uzunluğu örneklenmiştir:

Kajan keerimni çugaalap şıdavas men. "Ne zaman geleceğimi söyleyemem.” (Kuular 2002: 197)

Meey kajan kelirimni bilbeen boor siler. "Benim ne zaman geleceğimi bilmiyorsunuz.” (Dongak 2010: 5).

Şkolaga ööredilge egeley beerge, başkılarımga, öörümge çünü çugaalaar men? "Okulda eğitim başladığında, öğretmenlerime ve arkadaşıma ne söyleyeceğim? (Kara-ool 2013: 131).

Oon köör bis. "Oradan bakacağız.” (Dongak 2010: 87).

... dürgen emçige baar sen ... “... hemen doktora gideceksin ...” (Kara-ool 2013: 28).

Yukarıdaki tek heceli ve $/ \mathrm{r} /$ veya $/ \mathrm{l} /$ sesleriyle biten eylemlere $-(X) r$ eki getirildiğinde yaşanan duruma benzer biçimde $/ \mathrm{y} /, / \mathrm{g} /, / \mathrm{p} /, / \mathrm{k} /, / \mathrm{m} /, / \mathrm{l} /$ ünsüzleriyle biten tek heceli eylemlere $-(X) p$ zarf-fiil eki eklendiğinde söz sonu ünsüzler düşer ve ikincil ünlü uzunluğu ortaya çıkar (İshakov ve Palmbah 2019: 41-42). Aşağıdaki ilk tümcede yer alan hööp < höm-üp ile ikinci tümcede görülen keep < kel-ip sözcükleri bu biçimsel ses bilim değişimine birer örnektir:

Mında iyi-üş sun, mıygak ölürüp, hööp kagdım. "Burada iki üç erkek veya dişi geyik öldürüp gömdüm.” (Monguş ve Kuular 1995: 118).

Şülüktü keep çugaalap körem. “Şiiri gelip oku bakalım.” (Kara-ool 2013: 27).

Tuvacada $a p<a l-\imath p$ ve $t \imath p<t \imath v-\imath p$ gibi sözcüklerde yukarıdaki açlklanan sebeple oluşan ikincil ünlü uzunluğunun kaybolduğu görülür. Tuvacada ap yapısı çoğunlukla yardımcı eylem olarak kullanılır. Aşağıdaki ilk tümcede bunun örneği görülmektedir. İkinci tümcede görülen tıptıp yapısında da ikincil uzun ünlünün yittiği görülmektedir (tıptıp < tıvıl-ıp):

... ol nomdan kiji çünü bilip ap bolurul .. “... o kitaptan insan neyi öğrenir ...” (Kara-ool 2013: 150)

A sen, kurumçu, kayın tıptıp kelgeniך ol? “Peki sen, ikiyüzlü, nereden çıkıp geldin?” (Lodoydamba 2005: 38).

Sözcük tabanı ile ek sınırında ikincil ünlü uzunluklarının görüldüğü bir başka durum, ünlü ile biten eylemlerin $-X r$ ad-eylem veya zaman ekini almasıdır. Bu durumda sözcük tabanında veya ekte herhangi bir ses değişimi yaşanmaz. Yalnızca eklenme sırasında iki ünlü yan yana gelir:

Dılda tabu deerge adaarı horuglug sös bolur. "Bir dilde tabu olarak adlandırılan söylenmesi yasak sözler vardır." (Monguş ve Kuular 1995: 30).

\subsection{Biçimsel ses bilim kaynaklı benzeşmeler}

Türk dillerinde eklerin tahmin edilebilir değişkeleri vardır. Söz konusu bu değişkeler ses bilimsel kurallarla belirlenmektedir (Erdem 2016: 251). Yani, her biçimbirimin eklendiği sözcügün özellikle son hecesindeki ünlü ile son ünsüzüne göre farklı alt biçimbirimleri vardır. Bu alt biçimbirimler genel olarak ünlü uyumları ve ünsüz benzeşmeleri ile ilgilidir. Türkçenin biçimsel ses bilim açısından en önemli

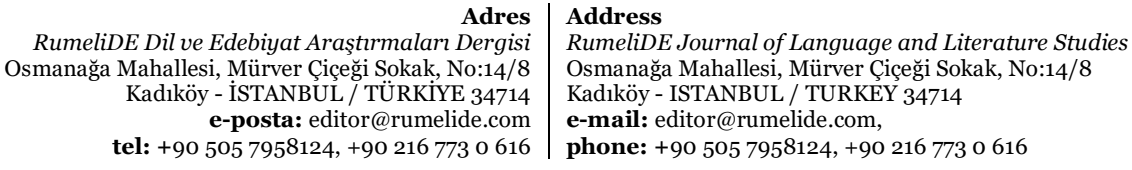


özellikleri arasında kök veya gövde ile ekler arasındaki ses uyumları (önlük-artlık uyumu, dudak uyumu ve ünsüz uyumları) yer alır (Demir ve Yılmaz 2018: 57). Bu anlamda daha geniş açıdan düşünüldüğünde her bir alt biçimbirimin oluşumu, biçimsel ses bilim ile ilgilidir. Ancak bu çalışmada amaç, Tuvacada eklerin genel sistemi üzerinde durmak değil; eklenme sırasında oluşan özel ses bilim değişmelerini incelemektir. Bu sebeple bu bölümde incelenen ünlü veya ünsüz benzeşmeleri, Tuvacanın genel ses bilim ve biçim bilim kurallarından farklı olarak kimi sözcük ve eklerde görülen ve standart Tuvacaya yerleşen örneklerdir. Birçok Türk dilinde olduğu gibi biçimsel ses bilim değişmelerinde Tuvacada da ilerleyici ve gerileyici benzeşme ile karışı benzeşme olmak üzere üç tür benzeşmeden söz edilebilir:

\subsection{1. Ünlü benzeşmeleri}

Ünlü benzeşmeleri Tuvacada çoğunlukla birleşme yoluyla sözcük yapımında görülür. Aşağıdaki ilk tümcede görülen bögün < bo hün sözcüğünde bo zamirinin ünlüsü, birleşme sirasında ikinci sözcüğün ünlüsü ile uyuma girerek /ö/ sesine değişmiştir. Aynı şekilde ikinci tümcede yer alan berten < bo erten sözcügünde de bo zamirinin ünlüsü, ikinci sözcüğün ünlüsü ile uyuma girerek gerileyici benzeşme neticesinde /e/ ünlüsüne değişmiştir.

Bögün ol uduy bergen ışkaş bolgan. "O, bugün uyuyor gibiydi." (Dongak 2010: 8)

Berten öşkünü şala onçaladım ... "Bu sabah keçini biraz kontrol ettim.” (Kara-ool 2013: 148)

\subsection{1. İlerleyici ünsüz benzeşmeleri}

İlerleyici ünsüz benzeşmeleri, kaynaklarda ünsüz benzeşmesi, fonolojik olarak koşullu alomorfi (Bacanlı 2014: 17), ek alomorflarında ünsüz nöbetleşmesi (Aslan 2006: 552) gibi farklı şekillerde adlandırılır. Biçimsel ses bilim kaynaklı, ilerleyici ünsüz benzeşmeleri, her Türk dilinde olduğu gibi Tuvacada da genel eklenme sistemine dâhil olmuştur. Bu sebeple daha önce de belirtildiği gibi sözcüklerin son hecesindeki ünlü ve son seslerindeki ünlü veya ötümlü-ötümsüz ünsüzlerine göre belirlenen alt biçimbirimler bu çalışmada ele alınmamıştır. Bir başka deyişle, biçimbirimlerin alt biçimbirimlerinin oluşumuna kaynaklık eden bu benzeşme örnekleri özel biçimsel ses bilim değişmeleri değildir. Örneğin, Tuvacada /1/ ünsüzünün birlikte kullanılabildiği sesler sınırlıdır. Bu sebeple eklenme sırasında /l/ sesine göre alt biçimbirim belirlenmektedir. Standart Tuvacada /ll/ ses çifti kullanılmadığı için $-L A r,-L X g$, $-L A$ - gibi biçimbirimler /l/ ile biten sözcüklere /d/'li biçimleri ile eklenmektedir (mal+dar "mallar", mal+dıg "hayvanlı", malda-ar "hayvan otlatmak" gibi). Görüldüğü gibi Tuvacayı pek çok Türk dilinden ayıran bir özellik olarak /l/ ünsüzüyle biten sözcüklere gelebilen alt biçimbirimler Tuvaca için standart bir kullanım hâline gelmiştir (Söz konusu addan ad yapan biçimbirimlerin Tuvacada ve Türk dillerindeki kullanımı için bkz. Tosun 2021; - LAr çokluk ekinin Türk dillerindeki kullanımı için bkz. Erdem 2015: 72).

\subsubsection{Gerileyici ünsüz benzeşmeleri}

Biçimsel ses bilim kaynaklı gerileyici ünsüz benzeşmelerine Tuvacada yalın durumda bo şeklinde kullanılan işaret zamirinin durum ekleri ile çekimlenmesi örnek verilebilir. bo zamiri durum ekleriyle çekime girdiğinde /b/ sesi /m/ olur. Burada görülen b- > m- değişimi, sözcüğün bünyesinde ortaya çlkan $n$ geniz ünsüzünün etkisiyle gerileyici benzeşme neticesinde gerçekleşir (Tosun 2011: 237; İshakov ve Palmbah 2019: 123).

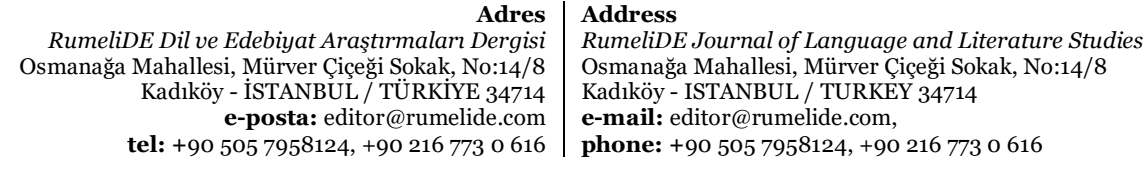

Adres
RumeliDE Dil ve Edebiyat Araştırmaları Dergisi Kadı̈̈y - İTTANBUL / TÜRKIYE 34714 tel: +90 $5057958124,+902167730616$

phone: +90 505 7958124, +90 2167730616 
Moon soygaar çerle ujuraşpaal. "Bundan sonra hiç görüşmeyelim.” (Kuular 2002: 69)

Tuvacada son hecesi - $l X n$ ile biten sözcüklere iyelik eki eklendiğinde vurgusuz orta hece ünlüsü düşer ve gerileyici benzeşme ile /l/ sesi, /n/ olur (İshakov ve Palmbah 2019: 45):

Çe, kennim, Ayanı açazı bagay bolgan ışkajıl. "Hadi gelinim, Aya’nın annesi sanırım kötü olmuş." (Kuular 2002: 77).

\subsubsection{Karışık benzeşmeler}

Tuvacada eklenme sırasında karışık benzeşme, çoğunlukla ünsüzle biten çok heceli eylemlere ünlü ile başlayan bir ekin getirilmesi sırasında görülür. Burada ilk olarak ünlü ile başlayan ekin neticesinde sözcüğün son hecesindeki vurgusuz orta hece ünlüsü düşer. Sonrasında ise sözcüğün ortasındaki ve sonundaki ötümlü sesler yan yana geldiği için benzeşmeye uğrayarak ötümsüzleşir (Koçoğlu Gündoğdu 2012: 74). Ayrıca İshakov ve Palmbah, Tuvacada görülen bu karışı benzeşme olayını, 'ikinci hecesi /j/ ve /g/ ünsüzleri ile başlayıp /n/ ünsüzü ile biten birden çok heceli sözcüklere ünlü ile başlayan ek getirildiğinde görülmektedir' şeklinde açıklamışlar ve örnek olarak ijin "karın” ve egin "omuz" ve sözcüklerini vermişlerdir. Bu sözcüklere ünlü ile başlayan ek getirildiğinde öncelikle vurgusuz ünlü düşer. Bu durumda hece başındaki /j/ ve /g/ ünsüzleri hecenin sonuna düşerek ötümsüzleşir. Yani, /j/ kendi tonsuz eşi /ş/ ile, /g/ ise /k/ ile değişir (ij-ni ve eg-ni yerine iş-ni ve ek-ni). Bu noktada Tuvacada ötümsüz bir ünsüzden sonra ötümlü bir ünsüz gelemeyeceği için /n/ sesi de ötümsüzleşir. Ancak /n/ sesinin ötümsüz bir karşılığı olmadığı için bu ses, aynı çıkış noktası olan patlayıcı tonsuz /t/ sesine

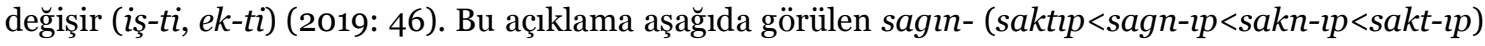
eyleminde olduğu gibi közül- ve bilin- eylemleri için de geçerlidir. Aşağıdaki ikinci tümcede görüldüğü gibi közül- eyleminde vurgusuz ünlü düştükten sonra hece başından hece sonuna geçen /z/ sesi, /s/ ile; hece sonundaki /l/ sesi de /t/ ile değişir (köstür<közül-ür<közl-ür<kösl-ür<köst-ür). Üçüncü tümcede yer alan minnip yapısında ise / $\mathrm{n} /$ sesi ile biten eyleme ünlü ile başlayan bir ek getirilmiş; bu durumda ilk olarak vurgusuz orta hece ünlüsü düşmüş ve hece başından hece sonuna geçen /l/ sesi benzeşmeye uğrayarak /n/ olmuştur. Eylemlerde görülen söz konusu benzeşme olayları, daha genel bir ifadeyle şöyle açıklanabilir: /n/ veya /l/ edilgenlik eklerinden biri ile biten birden çok heceli eylemlere ünlü ile başlayan bir ek getirildiğinde önce vurgusuz orta hece ünlüsü düşer, sonra söz içi ve söz sonu ünsüzler benzeşmeye uğrar. Burada sonu /l/ sesi ile biten eylemlerde karışık benzeşme, /n/ ile biten eylemlerde ise gerileyici benzeşme olmaktadır (minnip "anlaşılıp" krş. kennim "gelinim"):

Bir hünnü saktıp çor men. "Bir günü hatırlıorum.” (Tosun 2011: 300).

Delgem şınaalar çaraş kıldır köstür. "Geniş vadiler güzel görünür.” (Monguş ve Kuular 1995: 40).

Oon ol minnip kelgen. “O, oradan anlaşıldı.” (Monguş ve Kuular 1995: 186)

Sereepey meey ektimge holun salgaş: ... "Sereepey omzuma kolunu atarak, ...” (Monguş ve Kuular 1995: 155).

\section{Sonuç}

Bu çalışmada Tuvacanın biçimsel ses bilimi; sözcük tabanında görülen biçimsel ses bilim değişmeleri, sözcük tabanı ile ek sınırında görülen biçimsel ses bilim değişmeleri, biçimsel ses bilim kaynaklı ikincil ünlü uzunlukları ve biçimsel ses bilim kaynaklı benzeşmeler olmak üzere dört temel başlık altında betimlenmiştir. Eklenme sırasında oluşan ses değişmeleri tespit edilirken eş zamanlı ve art zamanlı değişmeler birlikte değerlendirilmiştir. Eş zamanlı biçimsel ses bilim değişmeleri, metin okumalarında, sözlük hazırlama ve sözlük kullanımında son derece önemlidir. Art zamanlı biçimsel ses bilim olayları ise Tuvacada hangi yapıların veya eklerin sözlükselleşme eğiliminde olduğunu görmek açısından değerlidir. Bu anlamda Tuvacada art zamanlı olarak sözcük tabanında biçimsel ses bilim yoluyla sözcük

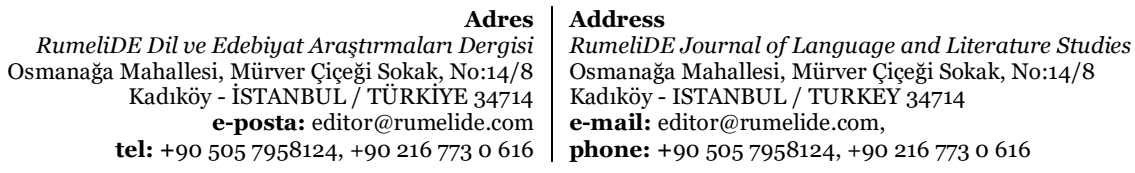


türetmede onluk saylları, çok sözcüğü, teg ilgeci ve bo zamiriyle kalıplaşan kimi sözcükler öne çlkmaktadır. Sözcük tabanında eş zamanlı biçimsel ses olayları ise vurgusuz hece ünlülerinin sıfırla nöbetleşmesi ile ilgilidir. Sözcük tabanı ile ek sınırında görülen biçimsel ses değişmeleri, çoğunlukla iki ünlü arasında kalan ötümsüz ünsüzlerin ötümlü karşılıklarıyla değişmesi şeklinde görülmektedir. Biçimsel ses bilim kaynaklı ikincil ünlü uzunlukları, Tuvaca için oldukça tipik bir ses olayıdır. Bu ikincil ünlü uzunluklarının görüldüğü durumlar şu şekilde özetlenebilir: 1. Sonu /r/ ve /l/ ünsüzleriyle biten kimi tek heceli eylemlere $-(X) r$ eki getirildiğinde, 2 . Sonu $/ \mathrm{k} /$ veya $/ \mathrm{g} /$ ile biten sözcüklere ünlü ile başlayan bir ek getirildiğinde, 3. Ünlü ile biten sözcüklere /g/ ile başlayan ekler getirildiğinde, 4. Aitlik ekinin ındı ve murnuu gibi örneklerde görülen sözlükselleşme sürecinde, 5. men ve sen kişi zamirleri ile $o l$ ve $b o$ zamirlerinin kimi durum ekleriyle çekimi sırasında. Tuvacada biçimsel ses bilim kaynaklı benzeşmeler ise; ünlü benzeşmeleri, ilerleyici ünsüz benzeşmeleri, gerileyici ünsüz benzeşmeleri ve karışı benzeşmeler olmak üzere dört bölümde incelenmiştir. Buna göre ünlü benzeşmelerinde bögün ve berten gibi sözcüklerde bo zamirinin etkisi görülmüştür. İlerleyici ünsüz benzeşmeleri yukarıda da belirtildiği gibi standart eklenme sistemine dâhil olduğu için bu çalışmada ele alınmamıştır. Gerileyici ünsüz benzeşmelerine, $b$ o zamirinde çekim sırasında ortaya çıkan /n/ ünsüzünün etkisiyle görülen b- > $\mathrm{m}$ - değişimi örnek verilebilir. Tuvacada eklenme sırasında meydana gelen karışık benzeşmelere ise sonu /l/ ve /n/ ünsüzleriyle biten sözcüklere ünlü ile başlayan bir ek getirildiğinde rastlanmaktadır.

Biçimsel ses bilim incelemeleri, bir Türk dilinin eş zamanlı olarak hem ses bilimi hem de biçim bilimi hakkında bilgiler verir. Bununla birlikte art zamanlı bir biçimsel ses bilim analizi; söz yapımı, dolayısıyla sözlük bilimi için önemlidir. Ayrıca Türk dilleri genel olarak karşılaştırmalı ses bilim ve biçim bilim şeklinde öğretilmektedir. Bu anlamda bir Türk dilinin biçimsel ses biliminin tespit edilmesi, çağdaş Türk dillerinin öğretimi açısından da büyük fayda sağlayacaktır.

\section{Kaynakça}

Aslan, S. (2006) Türkiye Türkçesinin Morfonolojisi Üzerine. Türk Dili, 654, 546-557.

Bacanlı, E. (2014). Türk Dillerinde Alomorfi Koşullanması, Türkbilig. 27, 13-39.

Demir, N. Ve Yılmaz, E. (2018). Türkçe Ses Bilgisi, Eskişehir: Anadolu Üniversitesi Açıöğretim Fakültesi Yayını.

Dongak, E. (2010). Kejik Kıs. Kızıl: Tıvanın Nom Ündürer Çeri.

Erdem, M. (2015). Türk Dili Tipolojisi Üzerine. Alkış Bitigi - Kemal Eraslan Armağanı içinde (Ed. Bülent Gül). Ankara: Türk Kültürünü Araştırma Enstitüsü.

Erdem, M. (2016). Dilbilgisi Konularında Devamlllık İlişkisi. Turkish Studies International Periodical fort he Languages, Literature and History of Turkish or Turkic, 11/10 Spring, 243-254.

Hazar, Erdem (2015). Türkçede Fono-Semantik ve Morfo-Fonolojik Yolla Sözcük Türetme. International Journal of Languages' Education and Teaching. 1648-1669.

İshakov, F. G. ve Palmbah, A. A. (2019). Tuva Dili Grameri Ses ve Şekil Bilgisi (çev. Ekrem Arıkoğlu, Canıl Mirza Bapayeva ve Buyan Borbaanay). Ankara: Bengü Yayınları.

Kara-ool, L. S. (2013). Literaturahg Nomçulga 3 Klass. Kızıl: Natsional Şkola Högjüder İnstitut.

Koçoğlu Gündoğdu, V. (2012). Günümüz Tuva Türkçesi (Giriş-Dil Özellikleri-Metinler-Söz Dizini). (Yayımlanmamış Doktora Tezi). Ege Üniversitesi Sosyal Bilimler Enstitüsü, İzmir.

Kuular, N. (2002). Düüşü̈nnerlig Eer-dagır Oruktar. Kızıl: Tıvanı’ Nom Ündürer Çeri.

Lodoylamba, Ç. (2005). Arıg Suglug Tamir (çev. Kırgıs Talayeviç ve Oydan-ool Hövenmey). Kızıl: Tivanın Nom Ündürer Çeri.

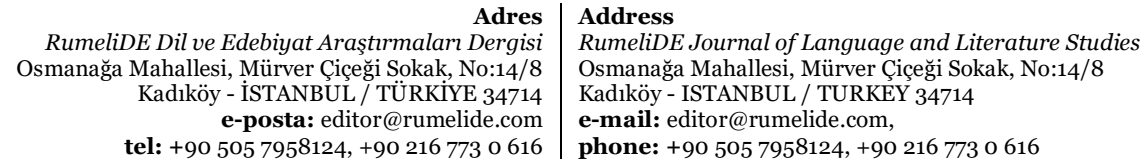


Monguş, D. A. ve Kuular, K. B. (1995). Tiva Dıl-Ortumak Şkolanı 6-7 Klasstarınga Ööredilge Nomu. Kızıl: Tivanın Nom Ündürer Çeri.

Ölmez, M. (2007). Tuvacanın Sözvarlğg - Eski Türkçe Ve Moğolca Denkleriyle. Wiesbaden: Harrassowitz Verlag.

Suvay, Ş. (2009). Hemçik Noyanı. Kızıl: Tıvanıy Nom Ündürer Çeri.

Tosun, İ. (2011). Tuva Türkçesinin Şekil Bilgisi (Yayımlanmamış Doktora Tezi). Trakya Üniversitesi Sosyal Bilimler Enstitüsü, Edirne.

Tosun, İ. (2021). Tuva Türkçesinde İsim Söz Yapımı. Çanakkale: Paradigma Akademi.

TRS = Tenişev, E. R. (1968). Tuvinsko-Russkiy Slovar. Moskva: İzdatel'stvo Sovyetskaya Ensiklopediya.

RumeliDE Dil ve Edebiyat Araştırmaları Dergisi Osmanağa Mahallesi, Mürver Çiçeği Sokak, No:14/8 Kadıköy - İSTANBUL / TÜRKIYE 34714 e-posta: editor@rumelide.com tel: +90 $5057958124,+902167730616$
Address

RumeliDE Journal of Language and Literature Studies Osmanağa Mahallesi, Mürver Çiçeği Sokak, No:14/8

Kadıköy - ISTANBUL / TURKEY 34714

e-mail: editor@rumelide.com

phone: +90 $5057958124,+902167730616$ 